Co-existence: a Middle Way between Assimilation and Cultural Resistance in Leila Aeboula Minaret

\title{
A Research Paper
}

Submitted by

\author{
Hala Mohamed Abdel-Raouf
}

Assistant Lecturer

Department of English

Assuit University - New Valley Branch

Egypt 


\section{Abstract}

Leila Aeboula (1964- ） is a Sudanese contemporary novelist. Her reputation as a pioneer of 'halal fiction' and her classification as a multicultural and postcolonial writer are the main reasons for an investigation of her novels. She is mainly concerned with the conflict evident between cultures. She always tries to find a middle way out of these cultural encounters. Minaret is an embodiment of her thought. The researcher tries to relate Aboulela's views to the theories of cultural conflict in postcolonial and multicultural contemporary fiction.

Key Words:Co-existence, Assimilation, Islam, , Nostalgia and Halal Fiction.

\section{Introduction}

Minaret is a story of a Sudanese girl called Najwa; she is an aristocrat whose lifestyle is westernized. She is a Muslim but not a religious devotee. Her best description is a 'cultural Muslim' based on whatGöranLarsson establishes: "By cultural Muslims I am referring to thelarge group of individuals who have a Muslim cultural background but do not practice Islam on a regular basis" (47). She is the daughter of a well- 
known politician. As a result of a military coup, her corrupt father is arrested and later hanged. This upheaval reshuffles her life; the girl who still studies at the university flees with her brother, Omar, and their mother to London.The focus of the study is to discover whether Najwaand the other characters could adopt the culture of the country to which they immigrate or not. It is also important to handle the issue of identity because the characters are abroad away from their nations living among others. "Processes of identity formation never occur outside socio-political and cultural contexts. They are no mere reflection of a free play of independent actors - they always require an opposite, the 'other' onto which the image of the 'self' is projected" (Kokot7). The study also handles assimilation and secularism because "Assimilation and secularism are related concepts that play a central role in the debates about minorities, migration and religion being held across Europe today" ( Jansen 14). The study also differentiates between assimilation and co-existence.

The characters in this work could be classified into two groups. Some characters adopt the British culture. Others highly stick to their religious identity. Susan TahaAl-Karawi notes this classification: "Aboulela provides her novel with the dichotomy of religious versus nonreligious people. Almost all devout Muslim people in Aboulela'sMinaret are represented as kind, sincere and selfless. It is the non-religious people 
who are represented as cruel, mean and shallow, generally providing a black-and-white picture" (258).The researcher is going to divide them sharply as westernized assimilated characters vs. culturally resistant ones. In addition, she is going to handle each character in the light of the role she/he plays in Najwa's life course pushing her to be "a way out of the stagnant binaries of West and East" (Smyth170).Aboulela conveys her themes through employing different narrative techniques including irony, contrast, flashback, stream of consciousness, internal and external perspectives. However, allusion is the most common technique in Minaret. Allusion is " an implicit reference, perhaps to another work of literature or art, to a person or an event ... When using allusions a writer tends to assume an established literary tradition, a body of common knowledge with an audience sharing that tradition and an ability on the part of the audience to 'pick up' the reference" (Cuddon 25).

\section{Assimilation}

Based on the following definition of assimilation, the study shows the extent to which the characters of Minaret assimilate with the British culture. Jansenpoints out that "Assimilation can be seen as a homogenising social process, in the course of which the members ofminorities, or of outgroups, are more or less forced to fully shed theirdifferences from a core 
group and, at the same time, acquire the cultural and civil competences of that core group" (21). Jansen adds that "In the context of migration,this core group is usually but not necessarily a national majority"(21). Members of minorities keep their culture aside because they believe that it is inferior to that of the country to which they migrate. This supports that although "Multiculturalism inherited anthropology's relativist, anti-elitist, and comprehensivenotion of cultures in the plural ... it also incorporated the preoccupationwith pride and shame inherent in the encounter between whatwere taken to be 'superior' and 'inferior' cultures" (JoppkeandLukes4).

Omar, a brother of Najwa, is one of theWesternized characters. For him,"anything Western was unmistakably and unquestionably better than anything Sudanese" (131-2).Use of 'unmistakably' and 'unquestionably' indicates that he totally believes in the superiority of the West. He is affected by the ideologies implemented by thecolonizer. One of the principal dogmas of Orientalism as reported by Said in his Orientalism"is the absolute and systematic difference between the West, which is rational, developed, humane, superior, and the Orient, which is aberrant, undeveloped, inferior" (300). ). Omar says: "I want to go to London. I hate studying here" (17). Ironically, he goes to London not as a student, but as a displaced refugee. Omar laments his luck because his cousin, Samir, goes abroad saying that Samir "gets to go abroad. And we get stuck here" (26). 
The verb 'stuck' is very significant; it implies being forced to stay in his country, Sudan. He is shown to listen to Bob Marley's "Misty Morning". Marley addresses "Misty Morning": "I want to straighten out my tomorrow." Misty Morning stands for Omar's life in the Sudan. He hopes that tomorrow which refers to the future in Europe to be better. Ironically, his life turns to be tragic in Europe and ends with him in prison. He is not interested in religion; he does not pray or fast. When Najwa asks him to read Quran, he responds: " "These religious things - they are not for everyone' " (94).

Anwar, a colleague of Najwa at the university, is another Westernized character. His character is a good indicator of the fragmentation theme which is a major postcolonial issue. He adopts antiimperialist convictions: he despises "Western music, Western ways" (25); he hates American songs and films (36).However, he seeks refugee in London and likes Najwa being Westernized because "The West is impressive" for him(149). Najwa does not dare to ask him "if he felt antiimperialist convictions contradicted seeking asylum in London" (156). However, he still hopes to go home. He always says: "If the government fell today I would go back tomorrow" (164). AnikóHatoss maintains: "While it is true that the majority of 'diaspora-like' populations tend to stay intheir country of migration, and large scale return movements are not 
realistic, many people aspire to move back to their homeland afterthe oppressing regimes have fallen and democracy makes its way to their new country of development" (8). Unlike Najwa, London for Anwar is "temporary, exotic" (168).Anwar has a misconception about freedom in Europe. He has a sexual relationship with Najwa justifying that they are free to do whatever they want as long as they live in Europe. Najwa says: "He put his arm around me because we were not in Khartoum ... We were free" (165).

While Najwa admires hair-covered women, Anwar rejects them as fundamentalists. He looks at the hair-covered Waffa, a friend of Najwa, as a backward fundamentalist. When he sees a couple of Arab women dressed in black from head to foot; their faces veiled, he points out: "It's disgusting, what a depressing sight" (167). For him, religion vs. being modern. He is a hard secularist. "The hard secularist usually professes atheism oragnosticism, although seldom publicly" (Martin 136). Consequently, he can not recognize the spiritual value of Ramadan. He can not understand that "Muslims fast during Ramadan so they canthink only about God. They give God their fullattention instead of thinking about food.Muslims also fast so they are reminded ofthose who are suffering. They think of peoplewho do not have enough to eat. They learnto be thankful for what they have" (Anderson 23). 
Randa is a Sudanese Muslim who studies in Britain.Her habits and her way of dress are British. Shewas born in England and came back with her parents with "eccentric English habits" (28). She admires Europe where there is "no power cuts. Civilization" (47). She has a boyfriend. Although she is a Muslim, she does not fast in London. For her and her family, Muslim rituals could not be performed in London. She says: "Last year we were in London and we didn't fast at all" (30). She justifies: " How can anyone fast in London? It would spoil all the fun" (30). She questions the significance of hijab. This proves that "[A]n obsession with the Muslim veil is not just a Euro- American phenomenon.Muslims themselves, especially in Muslim- majority societies,have also focused on the significance and symbolism of veiled women" (Amer4).She prays only "in exam time" (29).She is to be classified as a 'soft secular'. "Another form of Muslim secularism, related to soft secularism ... This type of secularism has grown in recent years among Muslim liberalswho may or may not be personally religious but generally they are not deniersof religion or deniers of the importance of religion in contemporary Islamic states" (Martin 140).

Lamya, Najwa'semployer in London, is another Westernized stereotype. She is non-religious. For her, "hijab is a fancy dress" (223). She despises Najwa because of the latter's hijab and her black colour. Najwa describes the nature of the relation between her and Lamya: "She will 
always see my hijab, my dependence on the salary she gives me, my skin colour ... she will never look beyond them" (116). This attitude towards veil represents a pressure for hair- covered woman. "The veil in this novel is furthermore symbolic of traditional Islamic culture and represents the struggle to be religiously faithful despite being surrounded by nonMuslims or non-practising Muslims" (Al-Karawi 255).She does not pray; "there is not even a prayer mat or tarha in her room" (99).Halal food is not an issue for her.Just like her brother,Lamya loses her national identity as DrZeniab, her mother, states: "My children are Sudanese in name only ... They don't remember the Sudan. We spent years in Oman ... and now we're in Cairo" (71).

Saleh, an uncle of Najwa, is a secondary character whose importance lies in the fact that he is one of the assimilated characters. He lives in Canada and prefers Western education. He does his best to take his son, Samir, out of Khartoum University and sends him to do the IB in Atlantic College in Wales. This makes Samir feel superior to Najwa and Omar who lose their fortune and prestige. Najwa points out: "It struck me that he was bored with us. As if something had happened to make us less than him. As if he was all grown up and we were still little" (60). This generates another kind of conflict based on social mobility. 


\section{Isolation: Cultural Resistance}

Tamer, a brother of Lamya, represents the characters that cannot adopt the culture of the country to which they immigrate. For him, "Islam $\ldots$ is a central marker ofidentity in the fragmentary world of migration, asylum, and family disintegration" (Chambers 88). His father is originally Sudanese and his mother is Egyptian.His "father wants him to study like he did in England" (85). Although he wants to study Islamic History, his father obliges him to Business. The fact that Tamer does not study what he likes makes him keep aside from his colleagues. He could not feel interested in Business study although he tries. He feels isolated not only from his colleagues but from all the British people. He cannot get adjusted to the British society; he does not have friends in Britainwhereas he had friends in Oman. He complains to Najwa: " 'I can't make friends here. I don't know why' " (209). He had lots of friends when he was studying in Oman but he cannot develop any kind of friendship in Britain. This indicates that the problem does not lie in Tamer himself but in the surrounding atmosphere. Najwa herself hints to this issue: "There are other places in London that aren't safe, where our presence irks people. Maybe his university is such a place and that is why he is lonely" (111). He is viewed as a terrorist although there is "a modest in him which his sister 
does not have" (100). Najwa describes him based on the Western look: "Tall, young, Arab-looking, dark eyes and the beard, just like a terrorist" (100). His appearance gives an impression of being a terrorist to the Western people. In his introduction to the revised edition of Covering Islam (1997), Said states: "Muslims and Arabs are essentially covered, discussed, and apprehended either as oil suppliers or as potential terrorists" (28).For the Western people, “the word 'Islam' imputes a unified and monolithic religious and cultural system, from which it is a small step to allude to the darkness and strangeness of Muslims, Arabs, their culture, religion etc" as Said argues in The Politics of Dispossession(373). This could explain why they have aggressive attitudes towards Muslims depending on the fact that"Attitudes towards other people and groups are linked to the way in which thetarget persons are perceived" (Bochner 18). As long as Tamer is susceptibly looked at, he cannot achieve success. "Success in school and in life is related to people's identity; how theyare viewed as a group and individually by others and how they seethemselves. Identity is not just a positive self-concept. It is findingyour place in the world with both humility and strength"(Reyhner39). This helps to support that"some groups have remained distinct not because they were strongenough to resist assimilation, but because they were exposed to coercive segregation (JoppkeandLukes141). 
This failure to coexist with people makes Tamer seek religion searching for his identity. He tries as possible as he can to perform Muslim religious rituals.Adhering to Muslim identity is reflected in his behaviour. For example,he wants to marry so as not to commit a sin unlike Anwar who does not feel guilty because of his sexual relationship with Najwa. For Tamer, it is a "religious obligation to celebrate" Eid. (190).He always listens to "Amr Khalid tapes" (99). The fact that he has tapes through which he communicates with the Muslim world highlights the role of technology in helping Muslims to feel home. "More than anything else the Internet and other information technologies provide spaces where Muslims, who often find themselves to be a marginalised or extreme minority group in many Western communities, can go in order to find others 'like them'" (Mandaville 146). Being interested in Amr Khalid implies that Tamer is not extremist because Khalid is known for his tolerance. He is far away from the terrorist figure comprehended by the Western people. "Amr Khalid has focused more explicitly on issues of community development, social change and dialogue between Islam and the West... Promoting social responsibility, Amrkhalid encouraged young people especially to develop themselves and their fellow citizens by actively participating in their communities" (Jung et al). "Unlike more orthodox preachers known for their joyless moralizing and austere 
methods, Khalid articulates the marriage of faith and fun" (Hammond 211).Khalid asks his followers to maintain Muslim values and enjoy life at the same time. Does Tamer apply the philosophy of Khalid? While Tamer sticks to Muslim rituals, he is extremely alienated from the West. Although he adopts the religious rules and principles, he feels detached from any worldly work even his study. He tells Najwa: "I did feel spiritually strong. I did reach a kind of detachment, like things didn't matter" (191). When she asks him about his studies, he responds: "I don't care anymore. Maybe the world will end and it won't matter what I study" (199). He spends Ramadan in the mosque and ignores his study and that's why he fails in his exams. He forgets that work is a worship for Muslims; he ignores that Islam gathers between worship and work. "There is nothing in Islam that commands a Muslim to withdraw from society in order to be closer to God. It is actually quite the opposite, and, in the Qur'an, believing is often, and almost essentially, linked with behaving well and doing good" (Ramadan 82). "Muslim identity is not closed and confined within the individual and personal domain as if it affects only the Muslim and the individual's relationship with God. On the contrary, to be Muslim entails adopting and articulating a perception of life based on faith, spirituality, and a basicunderstanding of moral injunctions" (Ramadan 81 ). 
The gap between Tamer and his family increases his sense of isolation. It could also justify why he falls in love with Najwa who is older than him. He informs Najwa: "I can't talk to anyone. I can only talk to you' " (201). In another occasion, he says to her: " 'You actually listen to me. You talk - most people don't talk - as if they have no time'" (208). She is the one to whom he complains about his sufferings and she listens. Thus, Tamer is an 'effective complainer'. Effective complainers "resort to people who are most likely to listen and to help them deal constructively with their dissatisfaction. Ineffective complainers complain to anyone who will lend them even half an ear (Kowalski 41).The fact that Najwa listens to him makes Tamer fall in her love, a love based on conversation just like that of Rae and Sammar in Aboulela'sThe Translator. They always go out and talk and never get lost in because they "see the minaret of the mosque and head towards it" (208). The minaret, after which the novel is entitled, is symbolic for religion. It is religion which guides and brings them together. Both of them look at Islam as an identity maker; it is more important than national one. For him, Islam is an identity maker. He maintains: "I don't feel very Sudanese though I would like to be. I guess being a Muslim is my identity" (110).

\section{Co-existence}


Although the assimilated characters stand against the culturally resistant ones in Minaret, Aboulela finds a middle way between them. GeoffreyNash offers a nuanced description of Aboulela's writing as one that is situated "within the feminized space which may be said to operate between the continuing pressures of Western cultural imperialism and conservative, anti-modernist cultural Islamism" (138). This is evident in the case of Najwa She has the ability to mix between different cultures at the same time. The best term to be used in such cases is hybridity."Hybridity rejects the notion of pure, original, authoritative identities, and gives value to the importance of limited categories and binaries" (Al-Karawi 260).This proves that "The crucial point is that, just acquisition of a new identity may not require complete acculturation, so it may not require the giving up of an old identity" (Barry 81 ). The ability of Najwa to mix between different cultures is related to her sense of being liminal as noted byAl-Karawi:

Najwa goes through individual, emotional and spiritual journeys while attempting to find a stable sense of identity in England or Sudan. Aboulela'sMinaret has two distinguishing parts: Najwaecs life before she wears the veil and after she chooses to wear the veil. In each part, Najwa is 
depicted struggling with feeling liminal, struggling to know and be who she really is. (261)

Liminality means to be between two stages; "Liminality, from the Latin word for 'threshold' (limen), connotes the position ofbeing betwixt and between" (Hynes 29).Najwa is liminal in the Sudan "as a university student because, although she is Sudanese, she does not particularly participate in regular Sudanese society" (Al-Karawi 261). She is different from the surrounding people by the virtue of her wealthy family's social position. Moreover, she adopts Western lifestyle among African people. This is reflected in the way she dresses. Her colleagues wear 'white tobes in contrast to her too short skirts and too tight blouses" (14)."As such, in Sudan, she has no real societal connections of her own rooted in cultural traditions or a social network of meaningful relationships that she can call her own. She has no personal experience of the Muslim veil and religious traditions that characterise her country's society" (Al-Karawi 261).

In London, her life is divided into two stages. During the first stage, she coexists with the British people doing the same depending on her fluent English, Westernized lifestyle and bank accounts. Her relation with the British people is that of alongside coexistence. Asante differentiates between two kinds of co-existence: 
Asante (2003b) ... implies that, if multiculturalismis defined as the co-existence of many cultures,there are two ways of cultural co-existence: (1) culturesin hierarchy and (2) cultures alongside. Cultures in hierarchyis the form of cultural co-existence in which wesee one culture above others so that we learn a frameof reference from one culture and view others throughthe single cultural standpoint. Cultures alongside is theform of cultural co-existence in which we see all culturesequal so that we learn different outlooks fromdifferent cultures and view all cultures through theirrespective cultural lenses. Asante (1993) refers to thesecond form of cultural co-existence as pluralism without hierarchy and hegemony. (qtd. in Miike 66)

As long as Najwa behaves like the British, they have no problem with her because she is not different from them. However, her alongside coexistence is interrupted by moments of memory. She always remembers the past through employing flashback andstream of consciousness techniques. She still uses Arabic terms such asTa'miyah, 'dilka', Ahlan, Doctora, zighni, suhur, kubeibah, andWudu. Although she speaks English very well, she does not keep her native language aside."The occurrence of linguistic assimilation does not imply that the language of origin is always 
lost. While people usually have only onereligion, they can easily master at least two languages if these are taught well" (Jansen 79). She listens to her "favouriteprogramme, The Golden Hour" (142) which handles past events. This is significant because it implies she is interested in the past which represents a happy memory for her, such happiness which she misses at the present time.

Najwa longs for the past not only because the past is better than the present but because no one compensates her for what she lost as well. She is frustrated"with all the male characters that play a central role in her life. Najwa"s father, her twin brother, her first lover Anwar, and even the devout Tamer all have serious flaws that "disappoint" her" (Chambers 111). She complains to Anwar: "But I had changed. My whole life had changed. There was just me. No Mama. no Baba, no Omar - just me, fumbling about in London" (150). All people cut from her even uncle and cousin. Although her uncle, Saleh, seems to be concerned about her at the beginning, his care lessens with time. This change could be attributed to displacement which degenerates people. "Displacement changes people in profound ways. It changes their political perceptions of themselves, other people, and the world. Refugees experience loss, cultural change, and regeneration" (Idris 68).Even Omar, Najwa's brother, who is supposed to play the role of a caring male is imprisoned.Here, the researcher has to 
elaborate on the irresponsible philosophy of Omar which leads to his fall down and hence he cannot support her. He is that kind of lazy and passive personality.Omaris shown to have a poster of Michael Jackson. He has "his hair just like Michael Jackson on the album cover of "Off the Wall" (11). This allusion has a great significance one has to focus on.José Igor and PrietoArranzstate:

$$
\begin{aligned}
& \text { "Songs such as "Get on the floor", "Off the Wall" ... explore } \\
& \text { the necessity to take pleasure in life ... "Off the wall" } \\
& \text { inviting the listener to indulge in pleasure and forget about } \\
& \text { responsibilities ... Jackson's ... Off the Wall(1979) } \ldots \\
& \text { owning a great debt to the disco music of the 1970s , which } \\
& \text { essentially underlined a discourse of escapism about } \\
& \text { enjoying life and forgetting any sort of existential } \\
& \text { responsibility." (98) }
\end{aligned}
$$

Even Anwar, Najwa's colleague, who is expected to be caring and loving is proved to be materialistic and opportunistic. For him, Najwa is a tool to improve his bad English. English is not only important for Anwar to communicate with others but it is important for him to compensatehis sense of inferiority as well. He has the colonial concept that the colonizer's 
language is superior to that of the colonized although "it is quite clear that no language can be described as better orworse than another on purely linguistic grounds" (Edward 90). Criterion of superiority is related to the power of those people who speak it. "We should agree that evaluations are notbased upon intrinsic qualities but rest, rather, upon socialconventions and preferences. These, in turn, are most obviously related tothe prestige and power possessed by speakers of certain 'standard' varieties" (Edward 96). As an opportunistic person, he exploits Najwa "to correct his English" (155).

While Najwa encourages and helps Anwar to get a high degree, he discourages her even to finish her undergraduate studies. She is the tool through which he wants to avenge aristocratic people represented in her. This could be deducted from the fact that he always teases her. "To tease is always to confront another personabout some aspect of his identity" (Kowalski 53). He confronts her about her corrupt father.When they are in the Sudan, he says to her that "It's bad enough I'm laughed at for going with you" (45). He says to her in London: "You and your family must be Home Office's ideal asylum seekers - a flat in London, bank accounts filled with the money your father swindled" (163). He always tries to bully her.His teasing is malicious; the envy is attributed to class barrier. While she and her family go every summer to Europe to spend holiday, he does 
not have enough money to make his blind sister get an operation (48). He refuses to marry her. As a result, she decides to end this forbidden relation, "To leave one forbidden thing is better in the sight of Allah than going to Hajj fifty thousand times" (245).This recognition is the beginning of following the right course. She does not like herself wearing a short skirt in public. She begins to have a kind of envy towards hair-covered women because they have something she does not have, something she does not have "a name for it" (134). Again, she is liminal between two stages. She neither devotes to nor rejects religion.

Najwa wears the veil willingly to negate what those who claim "that young women are forced by their families to wear the veil, and thatbanning it will free young women from such oppression" (15Hoodfar). Wearing hijab represents the beginning of a new stage for her in London. Jelodar argues that this "voluntary veiling is believed to be an empowering tool of self-expression through which women increase their relationship with their own faith and culture in addition to the fact that the incentive behind voluntary veiling re-establishes a link with authentic past culturally and its dissociation from the West" (qtd. in Al-Karawi 256). She begins to search for integration and seeks it in Islam. She tries to compensate for her family through fulfilling religious spiritual needs. Aboulela maintains:"In particular when I was writing Minaret I wanted to show that a woman's 
need for spiritual fulfillment is as urgent and as valid as her need for love, family and career" (Chaudhry1).

Najwa begins to co-exist with Muslims who keep their national identities aside and stick to their Muslim identity.All feel equal; Najwa recognizes this sense of equality: "I realize in the middle of the prayer that I don't know who is next to me" (79). Thus, her co-existence with Muslims is alongside.On the other hand, she notices that the non- Muslim Europeanschange their attitude towards her in the light of their Islamphobia?Is it possible for hair-covered Najwa to live among people whose conception about Islam is skeptical? Should Najwa give her religious beliefs up to fit into the British society?Some critics claim that the idea of the Muslim community in Britain and the freedom to perform religious rituals implies a democratic atmosphere. WilliamSafran maintains:

The retention of diasporic identity depends on the political institutions,ideologies, and policies of the hostland. In principle, diasporic identity is easier tomaintain in democratic countries than in authoritarian ones, for the ability ofcitizens to define their cultural and social spheres, including their cultural andsocial relations to another 
country, is part and parcel of personal freedom - aslong as such behaviour does no harm to the hostland and does not offend its democratic values. (18)

On the other hand, others claim that the Muslims resort to form a Muslim community because of their isolation sense. BassamTibi argues:

It is deplorable that most Europeans continue to view Muslims living in Europe- even those who were born there- as aliens. European states identify Muslims as immigrants, or 'people of migratory backgrounds.' Some view even European- born Muslims as intruders, fostering Islamophobia. Conversely, most of these Muslims do not feel at home in Europe, nor do they identify with European values; they compensate for their alienation by establishing their own ghettos. (157)

The situation in Minaret supports the second argument. While the hair-covered Najwa catches the bus, three guys call her a "Muslim scum" (81). Najwa is viewed by the Westerners as a scum because of her veil.For them, the Muslim hair-covered Najwa is an ethnic stereotype whose veil bring to their mind terrorism pictures. "Ethnic stereotypes, those 'pictures in our heads' that give us the impression that we know what 'they' are like 
even before we have actually met them" (Klineberg48).Thus, there is always a conflict between these varied cultures although cultures are supposed not to be imposed upon each otherin a multicultural society. However, Najwa tries to coexist with the British but they do not have a religious tolerance towards her although she speaks their own language. This situation assures Aboulela's mistrust in language. "A shared language is not any kind of basis for asense of belonging in London itself, either.... while English serves as a lingua franca in the mosque, it is also a medium of hatred elsewhere, as when the boys on the bus shout Muslim scum!" (Gilmour 9).Thus, while her co-existence with the Muslims in Britain is alongside; her co-existence with non- Muslims turns to be hierarchy because they begin to recognise her difference from them.

With this new character, Najwa seems to be a qualified wife for Tamer. Each one of them thinks of himself/ herself as "a Muslim" (110).However, he kisses Najwa who narrates what happens exactly: "He should not come close to me but he does and I cling to him, I cling to him I am sour and he is sweet. He kisses me and he does not know how. I should push him away, not let him learn, but his smell holds me still" (224).This kissing scene is not only important because Najwa is dismissed as a result, but because it pushes the reader as well to ask if it is an acceptable scene in a novel established as a 'halal'fictionwhich is supposed to be "entertaining 
without murders, illicit affairs, bad language, and other wasted wordage on heinous acts" (Ismail).Why does Aboulela employ this scene? Although it is not the first time in the novel Aboulela handles sex theme, it is the first time to be set in this explicit way.The only justification for this scene is that Tamer is human; "he doesn't know how" (224). This may be an intended scene by the author who wants to prove that the religious Tamer is a human being who has his wordy desires. Moreover, Tamer could be forgiven because he does his best to marry Najwa but his parents refuse. He wants to marry her because he wants to please God; he does not "want to commit a sin" (254). He ignores age barrier between them, a fact could not be ignored by people like Shaniz, a friend of Najwa, who addresses Najwa saying: "And you can't marry a man you don't look up to. Otherwise how can you listen to him or let him guide you?" (215) However, Tamer depends on the fact that "the Prophet, peace be upon him, married Khadijah and she was fifteen years older than him" (263). Naively, he does not recognize the differences between the two cases. He does not recognize that his need for Najwa is pushed by his family fragmentation. He does not recognize that the importance of Najwa lies in the fact that she is a good listener to him, a role could be played by someone else. Moreover, he is not that protecting man whom Najwa needs. He is still young and easily led by his parents and his sister. 
The kissing scene is also important because Dr. Zeniab decides to take Tamer back to Cairo and study Islamic History as a result. Najwa visits Tamer and his mother before they leave to Cairo to pay them goodbye.In her way to Tamer's house, Najwa sees "the minaret of the mosque above the trees" to show the importance of this mosque for her; it is to compensate her for the lost Tamer(269). Supported by money given by Zeniab, she decides to go hajj. Thus, religion is her salvation; it compensates her for lost family, home and love. MikePhillips argues: "Najwa's conversion is not an easy surrender to tradition. Instead it is a hard-won dedication to service, a kind of restitution for her former life, and the ending of the book is a disturbing hint that the peace she has achieved is contingent and subject to perpetual challenge" (1). What is important about this 'conversion' is that no one imposes upon her to change her way of life; it is her own decision. This decision indicates how much she has become self- dependent. It also supports the idea that "At the same time that forced migration entails profound loss, displacement also opens up possibilities for change" (Abusharaf 39).Moreover, it declines the secular argument "that religion will inevitably decline with modernization" (Turner 27). Religion is the superpower which helps Najwa to endure the fact of being separated from Tamer. This is early highlighted in the novel when the author alludes to ThePowerpuff Girls, a cartoon. Najwa and Tamer 
"drink tea together and watch ThePowerpuff Girls with Mai" (119). Intertextuality is employed here to make the reader link these two imaginary works to each other. The Powerpuff girls have superpower which help them to fight criminals and thereby survive. Like them, Najwa has akind of superpower, but her power is spiritual represented in heradherence to religion. It is this power whichempowers her to survive among hostile people. She surrendersonly with the help of superpower which implies that her love to Tamer has been great. Najwa needs a superpower to endure the bitter fact that she misses a part of her microcosm or her family; Tamer is a part of her family based on the idea that "Everyone you care for and who cares for you is family" (Vargas 27).

Despite his separation from Najwa, Tamer achieves a kind of selfefficacybecause he is going to study Islamic History in Cairo, something he wishes to do. "Self-efficacy is the idea that people feel good aboutthemselves when they can do things they want to do" (Reyhner 122). The fact that Tamer has the choice to go back to his home country at any time unlike Najwa highlights a great point of difference between them. While Najwa is diasporic person, Tamer is a transnational one based on whatMichelBruneau establishes: 
It is, in my view, this relationship to places and territories that enablesus to distinguish between diasporism and transnationalism.Diaspora implies a very strong anchoring in the host country and sometimes, when the home country is lost or is not accessible ... a clear-cut break with it.This is compensated, in the host country, by the creation of territorialmarkers, places of memory... That gives some kind of autonomy from hostand origin societies to the diasporic social formation compared to thetransnational community. In transnational spaces and territories of mobility,this break does not take place, nor is there the need to be rerootedelsewhere on the host territory. Any particular family has twoparallel lives in two or more nation-states: the home country is dominatedand the host countries, where the family has migrated, are dominant. (49)

It is true that devotion to religion helps Najwa to overcome a lot of obstacles and turns her to a better person. This supports that "religiosity is linked to well-being andother positive outcomes ... seems to buffer the practitioner against the negative impact of discrimination, work stress, and 
other negative life circumstances" according to a growing set of evidence (Kim-Prieto 4-5). In this regard, she clearly stands against the atheist Anwar whose ideology is based on the idea that "Religion has had the disastrous effect of placing vitally important concepts, such as morality, happiness and love, in a supernatural realm inaccessible to man's mind and knowledge (Smith 20). However, this does not negate certain passive features in the character of Najwa. Being religious does not cancel the fact that she is still naive. She always links between shortness in rituals performance to any bad thing happens. She believes that she and her family have become miserable because they were not praying in the past. "If Baba and Mama had prayed ... if I had prayed, all of this wouldn't have happened to us. We would have stayed a normal family" (95). She believes that Omar is imprisoned because his mother "cursed him with bad luck and Allah listens to a mother's prayer" (197). She does not recognize that God tests peopleto backward to him. The transformation also could not make Najwa forget about the past. When she prays next to the wife of Senegalese Ambassador, she elaborates on the past: "I didn't tell her that, once upon a time, diplomats like her husband and even the president on the Sudan were regular visitors in my father's house" (188). On the one hand, this situation highlights equality in Islam among other people from different classes: a wife of an ambassador and a servant praying next to each, an equality 
which is highlighted in another situation when Najwa'sMaths lecturer prays "his shoulder brushing against the gardener's" (43). On the other hand, it indicates that Najwa could not accept her status quo even unconsciously. Moreover, this transformation does not purify her heart. She is proved to be envious and jealous:"Jealousy admits of two senses. One has to do with being especially desirous of an advantage that another has, particularly an advantage that another seems to have preempted one from having. The other has to do with being especially desirous of maintaining the special relationship that one has with another" (Badhawr 63).She feels "a pang of envy" when Tamer wants to go home to "patch up his quarrel" with his mother(267). She envies him because he has a family, something she misses. She does not envy him as a person but she envies the idea that he has a family while she does not. She also envies Randa because the latter has all what Najwa misses: "But it would be painful to see her successful, fulfilled with parents and a career waiting back home. I would not be able to keep my envy under control" (236). She envies Shaniz because her life "moves forward, pulses and springs. There is no fragmentation, nothing stunted or wedged. I circle back, I regress; the past repeating itself, a scratched vinyl record, a stutter" (216). She envies DrZeniab because she is "professional, capable and mobile, not bogged down" (205). She is aware of this defect as it is evident in her elaboration on a hadith said the Prophet 
Muhammed, peace be upon him,: "'Envy devours your good actions like fire devours fuel' " (205). She is clearly stated to be envious although she once says about herself: "I owe myself an absence of envy; I owe myself a heart free of grudges" (73). This religious transformation also does not make Nawja feel the same like the British Muslims to whom she compares herself. She recognizes the differences: "Usually the young Muslim girls who have been born and brought up in Britain .... They strike me as being very British, very much at home in London. ... They have individuality and an outspokenness I didn't have when I was their age, but they lack the preciousness and glamour we girls in Khartoum had" (77).

\section{Conclusion}

Minaret is one of Leila Aboulela's major novels. It is a story of a Sudanese Muslim aristocrat called Najwa who is forced as a result of a military coup to seek refuge in Britain where she 'comes down' but finally she finds her right way through sticking to her Muslim identity. Najwa is a middle way between two contradictory sides: Westernized characters vs. culturally resistant ones. Westernized characters assimilate with the British people; they do without their Sudanese Muslim identity and acquire the culture of the country to which they migrate. They not only view themselves inferior to the Western people but they suspiciously look at 
Islam and its main concepts such as fasting and veil as well. As a result, their relation to the hosting people is that of alongside co-existence. While the Westernized characters are the main stream in the novel, only one character is resistant to assimilation. Tamer, is culturally resistant; he keeps isolated from the British people. He is viewed as a terrorist by the Western people because of his long beard despite the fact that he is more moderate than his Westernized sister. They recognize his difference from them and that's why his relation to them is that of hierarchy co-existence. Finally, he leaves to his homeland which implies his failure to co-exist with the British people.

Aboulela who employs different techniques mainly allusion, does her best to find a middle way out of these binary oppositions. This is done through the character of Najwa whose different life stages are highlighted. Najwa has the ability to mix between varied cultures; this ability is related to the fact that she is always liminal between two stages. She adopts the Westernized lifestyle in London and assimilates with others but she cannot forget her flourished past in the Sudan. At a certain moment she feels fed up with this Westernized lifestyle because of a religious aspect hidden inside her. She has a liminal period in which she feels guilty because of her tight clothes and sexual relationship. Then, she puts hijab which comes to stand for her Muslim identity and differentiates her from others who 
aggressively attack her because of their stereotypical concepts about veil. However, she co- exists among them inspite of her difference from them supported by religious power. Religion also empowers her to accept the fact of being separated from her beloved. The novel ends with Najwa in her London flat waiting for going hajj. Hajj is a great symbol of religion, religion which is earlier symbolized by the minaret of the mosque after which the novel is entitled.

Finally, there are some notes which should be referred to; these notes could contribute to a fresh reading of Minaret. First, despite all of the conflicts evident between the Arab characters in Minaret, they are still Arab in contrast to the Western others who are represented by the American boy at the American club in the Sudan who is judged to be American by the way he holds himself "conscious of this unglamorous part of the world he had been posted to" (25). The same point is also evident in the attitude of the two English girls who attend the party hold by Lamya. They "wear dark mini- skirts and hold their glasses tight in their hands. They look slightly bewildered, ruffled by culture shock" (221). Although use of the 'look' is a good example for the fact that Najwa cannot go inside their minds; it is clear that they are culturally shocked. Despite being small incidents, they reflect a great issue; colonizers could not completely agree with colonized people even Westernized ones. Second, it is also noted that 
all the displaced characters, whether they are diasporic or transnational, share a common feature which is identity loss and fragmentation resulting from displacement. ThomasBonnici argues: "The severing of people from their homeland, their culture and language causes loss of identity followed by a deep effort to appropriate, transform and merge local cultures with their traditional ones" (2). This fragmentation is paralleled by the division of the novel into four parts through employing non-linear narrative technique wherein events do not follow each other consequently. Third, although the British people are actually aware that "freedoms should be respected as long as they do not infringe on the rights of others", they have a problem with veil even it is based on personal decision(Kjaerum62). Moreover, the fact that Muslim veil is discussed as a great threat in the West enhances that "A society cannot be multicultural to an extent where anything is permitted by referring to culture and religion" (Kjaerum62). Fourth, there is a mistrust of language ability to bring people together; language is not a necessary basis for understanding in Minaret. Anwar and Najwa fail to communicate although both speak Arabic. Najwa does not share understanding with Um Waleed, a Syrian teacher, despite the fact that they both speak the same languages: English and Arabic.

To conclude, it could be said that while some critics criticize Minaret as lacking depth because of the sharp contrast between practicing 
and non-practicing Muslims; others praise it. For example, Smith says of Minaret:"Clear and precise writing, sympathetic characters, and positive portrayals of Muslim religious practices lend thiselegantly crafted novel broad appeal" (63).

\section{Works Cited}

Abusharaf,Rogaia Mustafa. Transforming Displaced Women in Sudan: Politics and the Body in a Squatter Settlement.Chicago And London:The University of Chicago Press, 2009. Print.

Al-Karawi, Susan Taha. "Negotiating the Veil and Identity in Leila Aboulela's Minaret."Journal of Language Studies 14.3 (2014): 255-268. Print.

Amer, Sahar. What Is Veiling?Eds,Carl W. Ernst and Bruce B. Lawrence.Chapel Hill: The University of North Carolina Press,2014. Print. Islamic Civilization and Muslim Networks. Anderson, Sheila. " Ramadan."Cultural Holidays. Edina: Magic Wagon, 2010. Print.

Badhwar, NeeraKapur, ed. Friendship: A Philosophical Reader. Ithaca and London: Cornell University Press, 1993. Print. 
Barry, Brian. Culture and Equality: an Egalitarian Critique of Multiculturalism. NP: Polity Press in Association with Blackwell Publishers Ltd, 2001. Print.

Bochner, Stephen, ed. "Cross-Cultural Interaction: Theory and Definition of the Field."Cultures in Contact: Studies in Cross-Cultural Interaction. Ed.Stephen BochnerOxford: Pergamon Press, 1982. 344. Print.

Bonnici, Thomas. "The Contemporary Post-Colonial Novel in English." Maringa. 26. 1(2004): 1-22. Print.

Bruneau, Michel. "Diasporas, Transnational Spaces and Communities." Diaspora and Transnationalism: Concepts, Theories and Methods. Eds. Rainer Bauböck and Thomas Faist. Amsterdam: Amsterdam University Press, 2010. 35-49. Print.

Chambers, Clare. An Interview with Leila Aboulela."Contemporary Women's Writing 3.1 (2009): 86-102. Print.

Chaudhry, Asma. "Leila Aboulela on Being a Writer." Northernchowk.12 Nov. 2012. Web. 27 March 2014.

Cuddon, J. A. A Dictionary of Literary Terms and Literary Theory. 5th ed. Wiley -Blackwell, 2013. Print. 
Edward, John.Multilingualism. London and New York: Routledge, 1994. Print.

Gilmour, Rachael. "Living Between Languages: the Politics of Translation in Leila Aboulela'sMinaret and XiaoluGuo's."The Journal of Commonwealth Literature 47. 2(June 2012). 207-227. Print.

Hammond, Andrew. "AmrKhaled: Modern, Sharply Dressed Preacher Man."Pop Culture Arab World!: Media, Arts, and Lifestyle.Santa Barbara, Denver and Oxford: ABC-CLIO,2005. Print.

Hatoss, Anikó. Displacement, Language Maintenance and Identity: Sudanese Refugees in Australia. Amsterdam / Philadelphia: John Benjamins Publishing Company, 2013. Print.

Hoodfar,Homa. "More Than Clothing:Veiling as an Adaptive Strategy." The Muslim Veil in North America Issues and Debates.Eds. Sajida SultanaAlvi, HomaHoodfar and Sheila McDonough.Toronto: Women's Press, 2003. 3-40. Print.

Hynes, Patricia.The Dispersal and Social Exclusion of Asylum Seekers: Between Liminality and Belonging Bristol: The Policy Press, 2011. Print.

Ismail, Maryam. "It's Fiction and It's Halal." New India. 6 November 2013. Web. 27 March 2014. 
Idris, Amir H. Conflict and Politics of Identity in Sudan. New York: Palgrave Macmillan, 2005. Print.

Igor, José and PrietoArranz, eds. De-Centring Cultural Studies: Past, Present and Future of Popular Culture. Newcastle Upon Tyne: Cambridge Schooling Publishing, 2013. Print.

Jansen, Yolande. Secularism, Assimilation and the Crisis of Multiculturalism: French Modernist Legacies. Amsterdam: Amsterdam University Press, 2013. Print.

Joppke, Christianand Steven Lukes ,eds. Multicultural Questions. Oxford and New York: Oxford University Press, 1999. Print.

Jung, Dietrich, et al. Politics of Modern Muslim Subjectivities: Islam, Youth and Social Activism in the Middle East. New York: Palgrave Macmillan, 2014. Print.

Kim-Prieto, Chu. "Introduction: Positive Psychology of Religion Across Traditions and Beliefs pages." Religion and Spirituality Across Cultures. Dordrecht Heidelberg and New York London: Springer, 2014. 1-18.Print. Cross-Cultural Advancements in Positive Psychology 9.

KjaerumMorten."Human Rights forImmigrants andImmigrants for HumanRights." International Migration and Security Opportunities 
and Challenges. Eds.Elspeth Guild and Joanne Van Selm. London and New York Routledge. 2005. 51-63. Print.

Klineberg, Otto. "Contact Between Ethnic Groups: A Historical Perspective of Some Aspects of Theory and Research." Cultures in Contact: Studies in Cross-Cultural Interaction. Ed. Stephen Bochner.Oxford: Pergamon Press, 1982. 45-55.

Kokot, Waltraud, et al., eds. Introduction.Diaspora, Identity and Religion: New Directions in Theory and Research. London and New York: Routledge, 2004. 1-8.Print.

Kowalski, Robin M. Complaining, Teasing, and Other Annoying Behaviors. New Haven and London: Yale University Press, 2003. Print.

Larsson, Göran. "Yusuf al-Qaradawi and Tariq Ramadan on Secularisation: Differences and Similarities." Muslim Societies and the Challenge of Secularization: An Interdisciplinary Approach. Ed. Gabriele Marranci. London New York: Springer, 2010. 47-64. Print. Muslims in Global Societies Series 1.

Martin, Richard C. "Hidden Bodies in Islam: Secular Muslim Identities in Modern (and Pre Modern) Societies." Muslim Societies and the Challenge of Secularization: An Interdisciplinary Approach. Ed. 
Gabriele Marranci. London and New York:Springer, 2010. 131148. Print. Muslims in Global Societies Series 1.

Mandaville, Peter. "Communication and Diasporic Islam:A Virtual Ummah?"The Media of Diaspora. Ed,Karim H Karim. London and New York: Routledge, 2008. 135-147. Print.

Miike, Yoshitaka. "Harmony Without Uniformity": An AsiacentricWorldview and Its Communicative Implications." Intercultural Communication: A Reader. Eds.Larry A. Samovar, Richard E. Porter and Edwin R. McDanie. Wadsworth: Cengage Learning, 2012. 65-80. Print.

Nash, Geoffrey. "Leila Aboulela: Islam and Globalization.” In The AngloArab Encounter: Fiction and Autobiography by Arab Writers in English. Oxford and Bern: Peter Lang, 2007. 135-147. Print.

Phillips, Mike. "Faith Healing."Rev. of Minaret, by Leila Aboulela.The Guardian.Guardian News and Media Limited or Its Affiliated Companies, 11 June 2005. Web. 16 Apr.2014.

Ramadan, Tariq. Western Muslims and the Future of Islam. Oxford and New York :Oxford University Press, 2004. Print.

Reyhner, Jon Allan.Contemporary Native American Issues: Education andLanguage Restoration. Philadelphia: Chelsea House, 2006. Print. 
Safran, William."Deconstructing and Comparing Diasporas." Identity and Religion: New Directions in Theory and Research.Eds. WaltraudKokot, KhachigTölölyan and Carolin Alfonso. London and New York: Routledge, 2004.9-30. Print.

Said, Edward.Covering Islam. New York: Vintage, 1997.Print.

_ _ . Orientalism. London: Penguin Books Ltd, 1978.Print.

_ _ _. The Politics of Dispossession:The Struggle for Palestinian SelfDetermination, 1969-1994. London: Chatto and Windus, 1994.Print.

Smith, George H. "Atheism:The Case Against God."Bibliophile 1.1 (Jan 2003). Web. 1 March 2016.

Smyth, Brendan. "To love the Orientalist: Masculinity in Leila Aboulela'sThe Translator." Journal of Men, Masculinities and Spirituality 1.2 (June 2007): 170-182. Print.

Tibi, Bassam."Euro- Islam: An Alternative to Islamization and Ethnicity of Fear." The Other Muslims: Moderate and Secular. Ed.ZeynoBaran. New York:Palgrave Macmillan, 2010. 157-174.

Turner, Bryan S. "Islam, Public Religions and the Secularization Debate."Muslim Societies and theChallenge of Secularization:An Interdisciplinary Approach. Ed. Gabriele Marranci. London New 
York: Springer, 2010. 10- 30. Print.Muslims in Global Societies Series.

Vargas, Roberto.Family Activism:Empowering Your CommunityBeginning With Family and Friends. San Francisco: Berrett-Koehler Publishers, 2008. Print. 